\begin{tabular}{|l|l|l|}
\hline \multicolumn{2}{|c|}{ PublisherInfo } \\
\hline \hline PublisherName & $:$ & Palgrave Macmillan UK \\
\hline \hline PublisherLocation & $:$ & London \\
\hline \hline PublisherImprintName & $:$ & Palgrave Macmillan \\
\hline \hline
\end{tabular}

\title{
UK environmental accounts: air emissions and energy use
}

\begin{tabular}{|c|c|c|}
\hline \multicolumn{3}{|c|}{ ArticleInfo } \\
\hline ArticleDOI & $:$ & 10.1057/palgrave.elmr.1410169 \\
\hline ArticleCategory & : & Feature \\
\hline ArticleFirstPage & : & 18 \\
\hline ArticleLastPage & : & 27 \\
\hline ArticleHistory & $:$ & $\begin{array}{ll}\text { RegistrationDate } & : 2007-11-16 \\
\text { OnlineDate } & : 2007-11-16\end{array}$ \\
\hline ArticleCopyright & . & Crown copyright 2007 \\
\hline
\end{tabular}




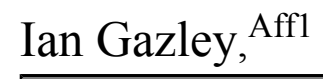

Aff1 Office for National Statistics

\section{Sets out the various definitions used, analyses the latest data and offers conclusions regarding trends that have emerged.}

ONS air emissions data show that between 1990 and 2005, total UK greenhouse gas emissions on a UK resident's basis fell 9.3 per cent from 808.3 million tonnes of carbon dioxide equivalent to 733.4 million tonnes. However, much of this reduction took place in the period between 1990 and 1999. Since 1999, emissions have remained broadly stable although there has been 20.5 per cent growth in economic activity. In contrast, the rate that energy consumption has increased over the whole period is relatively stable: between 1990 and 1999 it was up 5.1 per cent and between 1999 and 2005 up 5.5 per cent. This article is divided into three parts, the first sets out various definitions used in the compilation of the air emissions and energy use accounts, the second part moves on to an analysis of the latest data set (consistent with data published in July 2007). In the third part of this article, some conclusions are offered regarding the trends that have emerged.

Misc

The Full Text of this article can be found on the National Statistics website (http://www.statistics.gov.uk/elmr/11_07/downloads/elmr_nov07_gazley.pdf). 